\title{
The role of the eco-financial sector in realizing the sustainable development goals
}

\author{
Lyudmila Glubokova ${ }^{1}$, Dmitry Kokhanenko ${ }^{2, *}$, Natalya Pislegina $^{2}$, Pavel Neverov $^{2}$, and \\ Kholnazar Amonov ${ }^{3}$ \\ ${ }^{1}$ Altai State University, 61 Lenin Ave., Barnaul, Russia \\ ${ }^{2}$ Altai Branch of Financial University Under the Government of The Russian Federation, 54 Lenin \\ Ave., Barnaul, Russia \\ ${ }^{3}$ European Institute of Applied Science and Management, Prague, Czech Republic
}

\begin{abstract}
The article examines the role of the eco - financial sector in the implementation of sustainable development goals through the creation of a new ecological system of global financial resources - a system of responsible and green financing. Favorable economic conditions and significant socioeconomic benefits are at the heart of banks' transition to responsible and green finance. Provided that these principles are implemented on an ongoing basis, in the near future, one can expect an increase in investments in environmental and social projects, and, as a result, an improvement in the environmental situation and an increase in the standard of living of the population different countries of the world. In this paper, the authors analyzed the main directions of development of a new ecological system of global financial resources - a system of responsible and green financing in Russia and abroad and the role of the eco - financial sector in the implementation of the UN sustainable development goals in terms of combating climate change, industrialization, innovation and infrastructure, affordable and clean energy, clean water and sanitation. The analysis showed that foreign and domestic banks and other financial institutions are actively involved in organizing and conducting the issuance of "green" bonds.
\end{abstract}

\section{Introduction}

In the context of the innovative and investment development of the economy, the study of the growing role of commercial banks in financing the non-financial sector of the economy and, as a result, in achieving the Sustainable Development Goals (SDGs), which were formulated in September 2015 at the historic UN summit in Paris, becomes very relevant According to experts, for the successful implementation of the UN SDGs, at least \$ 30 trillion will be needed. To accumulate and use funds in the right direction in the world economy, a new ecological system of global financial resources is being created - a system of responsible and / or green finance (hereinafter referred to as the green finance ecosystem), which is based

\footnotetext{
*Corresponding author: dimvsl@yandex.ru
} 
on the unity of three interrelated ESG factors - ecology, social issues and corporate governance. In light of this, the role of commercial banks and other financial institutions in a continuous investment process focused on financing long-term innovative projects in the real sector of the economy is of particular importance.

In May 2016, the PRI launched the ESG in Credit Risk and Ratings Initiative to advance the Paris Agreement goals. To date, 151 financial companies with a combined capital under management of more than $\$ 30$ trillion have committed themselves to disclosing information on ESG factors in investment strategies, as well as in prospectuses of securities of issuing companies INFRAGREEN. [1]

In addition to management companies, this initiative was supported by 18 rating agencies, which undertook to take into account ESG factors when assessing the credit quality of issuing companies: international rating agencies Moody's Corporation, S\&P Global Ratings, Fitch Group, Inc, Chinese China Chengxin International Credit Rating Co. Dagong Global Credit Ratings Group, European Rating-Agentur Expert RA GmbH, Turkish JCR Eurasia Rating and others. The information basis for the formation of such ratings is the company's report on sustainable development, prospectuses for the issue of securities, and other information.

In February 2019, the Association for Responsible Investment (PRI) launched an initiative from 2020 to introduce mandatory disclosure for its members on measures taken in the field of managing the risks of changing the climatic conditions of activity. Since January 1, 2020, more than 480 financial companies that manage \$ 42 trillion in capital have voluntarily committed themselves to disclose climate change risks.

In December 2017, at the Paris One Planet Summit, eight central banks initiated the Network for Greening the Financial System (NGFS). Its goal is to strengthen the global response needed to achieve the Paris Agreement goals and to enhance the role of the financial system in managing risk and mobilizing capital for green and low-carbon investment in the broader context of environmentally sustainable development. [2]

Studies have shown that Russia is gradually joining the modern global ecosystem in the field of sustainable development and responsible investment practices. Based on the statistics of non-financial reports published by Russian companies and registered in the National Register of Non-Financial Reports, which is maintained by the Russian Union of Industrialists and Entrepreneurs, as of April 11, 2019, 924 reports have been registered, issued since 2000. These include: environmental reports - 81, social reports - 326, sustainability reports - 314, integrated reports - 176, industry reports - 27. Oil and gas companies are the undisputed leader in the preparation of non-financial reports. [3]

Taking into account modern global trends, Russian banks are already transforming their business processes in accordance with the principles of the "green" financing system, which in the long term will help to improve the environmental situation in our country and create more favorable living conditions for people.

The purpose of the study is to determine the main directions for the development of a new ecological system of global financial resources - a system of responsible and / or green financing in Russia and abroad and the role of the eco - financial sector in the implementation of the UN sustainable development goals.

To achieve this goal, it is necessary to perform the following tasks:

- to study the mechanism of formation of the green finance ecosystem in Russia and abroad;

- to analyze the volumes of emission of "green" bonds in Russia and abroad and the role of the eco - financial sector in this process;

- to assess the prospects for the development of the market for "green" bonds as a source of financing for environmental projects aimed at improving the environmental situation in the world and in Russia. 


\section{Materials and Methods}

The study of the mechanism for the formation of a green finance ecosystem was carried out on the basis of publicly available data contained in the reports of the Bank of Russia, Rosstat data, annual reports of commercial banks, data from the National Register of Non-Financial Reports, as well as reports of Russian and international rating agencies.

Within the framework of the study, the methods of systematization, classification, analogy, comparison and logical research were used on the basis of a creative information approach, as well as generalization of special literature on the topic.

Analysis of the historical aspect of the formation of an ecosystem of green financing of environmental and social projects in the world made it possible to identify the stages presented in Table 1.

Table 1. History of the development of the green finance market in the world.

\begin{tabular}{|c|c|c|c|}
\hline Stages & $\begin{array}{l}\text { Time } \\
\text { period }\end{array}$ & Event & Green finance market instruments \\
\hline 1 & 1968 & $\begin{array}{l}\text { For the first time, the UN General } \\
\text { Assembly began to consider issues } \\
\text { related to environmental problems and } \\
\text { climate change }\end{array}$ & \\
\hline 2 & 2007 & $\begin{array}{l}\text { Publication of the report of the UN } \\
\text { Intergovernmental Panel on Climate } \\
\text { Change, based on } 20 \text { years of study of } \\
\text { the history of climate change, } \\
\text { revealing the negative impact of } \\
\text { humans on climate change }\end{array}$ & First-ever Climate Awareness Bond \\
\hline 3 & $\begin{array}{l}2008- \\
2012\end{array}$ & & $\begin{array}{c}\text { Issue of "green" bonds by supranational } \\
\text { financial corporations (World Bank, European } \\
\text { Investment Bank (EIB), International Finance } \\
\text { Corporation (IFC) }\end{array}$ \\
\hline 4 & 2013 & & $\begin{array}{l}\text { Placement of the first corporate and municipal } \\
\text { green bonds in the amount of } \$ 11.5 \text { billion. } \\
\text { In } 2013 \text {, the US government of Hawaii issued } \\
\text { green infrastructure bonds to finance the } \\
\text { modernization of local power plants }\end{array}$ \\
\hline 5 & $\begin{array}{l}\text { Januar } \\
\text { y } 2014\end{array}$ & $\begin{array}{c}\text { International Capital Markets } \\
\text { Association (ICMA) publishes Green } \\
\text { Bond Principles }\end{array}$ & $\begin{array}{l}\text { Growth of the green bond market more than } 3 \\
\text { times. The volume of issued bonds amounted } \\
\text { to } \$ 36.3 \text { billion }\end{array}$ \\
\hline 6 & 2015 & $\begin{array}{l}\text { Paris Agreement on Climate Change } \\
\text { (ratified by } 170 \text { countries). } \\
\text { Adoption of } 17 \text { Sustainable } \\
\text { Development Goals by } 2030 \\
\text { China - publishes green bond issuance } \\
\text { guidelines and green project criteria }\end{array}$ & $\begin{array}{l}\text { Growth of the green bond market to } \$ 41.8 \\
\text { billion. }\end{array}$ \\
\hline 7 & 2016 & & $\begin{array}{l}\text { Growth of the green bond market to } \$ 81.0 \\
\text { billion. }\end{array}$ \\
\hline 8 & 2017 & $\begin{array}{l}\text { Southeast Asia Association publishes } \\
\text { Green Bond Standards }\end{array}$ & $\begin{array}{l}\text { Growth of the green bond market to } \$ 162.1 \\
\text { billion }\end{array}$ \\
\hline 9 & 2018 & $\begin{array}{c}\text { European Commission approves } \\
\text { Financing Action Plan for Sustainable } \\
\text { Development } \\
\text { In March 2018, the Credit Market } \\
\text { Association (LMA) publishes the } \\
\text { Green Loan Principles }\end{array}$ & $\begin{array}{l}\text { Growth of the green bond market to } \$ 170.6 \\
\text { billion }\end{array}$ \\
\hline 10 & 2019 & & $\begin{array}{l}\text { Growth of the green bond market to } \$ 57.7 \\
\text { billion }\end{array}$ \\
\hline
\end{tabular}

Source: (Compiled by the authors) 
The data given in Table 1 clearly demonstrates the main trend of growth in the volume of emission of "green" bonds over the studied period of time. This is due to the fact that:

- the demand for these bonds is several times higher than their supply;

- there is a need to restore the economies of countries after the COVID-19 pandemic;

- the coupon rate on these bonds is lower than on ordinary bonds;

- the risk associated with the loss of liquidity for these bonds is lower than for conventional and other factors.

The main constraining factor limiting the growth of the emission of green bonds, many experts call the shortage of green projects and green assets, on the investment of which attracted funds can be spent.

An analysis of the directions of spending the funds received from the emission of "green" bonds is presented in Table 2 .

Table 2. Directions of distribution of funds received from the issuance of green bonds, $\$$ bln.

\begin{tabular}{|c|c|c|c|c|c|}
\hline \multirow{2}{*}{$\begin{array}{c}\text { Directions of } \\
\text { distribution of funds }\end{array}$} & \multicolumn{4}{|c|}{ Analyzed period } & \multirow{2}{*}{$\begin{array}{c}\text { Growth rate } \\
2019 / 2016, \%\end{array}$} \\
\cline { 2 - 5 } & 2016 & 2017 & 2018 & 2019 & 143 \\
\hline Renewable energy & 33 & 51 & 53,1 & 80,2 & 293 \\
\hline Low carbon production & 19 & 45 & 50 & 74,8 & 297 \\
\hline Clean transport & 13 & 24 & 34,2 & 51,6 & 98 \\
\hline Water management & 12 & 20 & 15,4 & 23,8 & 77 \\
\hline Waste management & 5 & 6 & 6,8 & 8,83 & 348 \\
\hline Land use & 2 & 5 & 5,13 & 8,96 & $-41,6$ \\
\hline etc & 5 & 4 & 5,13 & 2,92 & \\
\hline
\end{tabular}

Source: (Compiled by the authors)

The information presented and systematized in Table 2 indicates that over the studied period of time, the highest growth rate is observed in investments in land use, followed by clean transport, low-carbon production demonstrates a slight lag behind it, negative growth dynamics is present only in other investments.

Analytical data on the issue of "green" bonds in Russia, obtained from the leading Russian and foreign rating agencies, as well as on the directions of use of attracted investments, are summarized and systematized in Table 3.

The data in Table 3 allow us to conclude that the growth trend of the green bonds market in the world economy is also observed in Russia.

Based on data on the volume of GDP, it can be said that the Russian economy is close to the ten largest countries in the world, then the Russian financial market is not even included in the first hundred. According to the World Competitiveness Index, the Russian financial market is below the Turkmen one. Therefore, a significant emphasis is now being placed on the development of the eco-financial sector. This sector is in a position to radically correct the situation, provide additional sources of less expensive money than in Russia for domestic green projects. 
Table 3. Issue of "green" bonds in Russia.

\begin{tabular}{|c|c|c|c|c|}
\hline $\begin{array}{c}\text { Name of } \\
\text { organization - bond } \\
\text { issuer }\end{array}$ & $\begin{array}{c}\text { Place, date, organizer } \\
\text { of placement }\end{array}$ & $\begin{array}{l}\text { Issue } \\
\text { volume }\end{array}$ & $\begin{array}{l}\text { Directions of using the } \\
\text { attracted funds }\end{array}$ & $\begin{array}{l}\text { Bonds validation } \\
\text { method }\end{array}$ \\
\hline $\begin{array}{l}\text { Company "Resource } \\
\text { Saving of KhMAO" }\end{array}$ & $\begin{array}{l}\text { Moscow Exchange, } \\
\text { December 19, } 2018\end{array}$ & $\begin{array}{l}1.1 \text { million } \\
\text { pieces with } \\
\text { a total par } \\
\text { value of } 1.1 \\
\text { billion } \\
\text { rubles }\end{array}$ & $\begin{array}{c}\text { Creation of an } \\
\text { integrated inter- } \\
\text { municipal landfill for } \\
\text { the placement, disposal } \\
\text { and treatment of MSW } \\
\text { for the cities of } \\
\text { Nefteyugansk, Pyt- } \\
\text { Yakha } \\
\end{array}$ & $\begin{array}{l}\text { European rating } \\
\text { agency Rating - } \\
\text { Agentur Expert } \\
\text { RA GmbH }\end{array}$ \\
\hline $\begin{array}{l}\text { JSC "Russian } \\
\text { Railways" }\end{array}$ & $\begin{array}{c}\text { September } 24,2019 \\
\text { The organizer of the } \\
\text { placement "VTB } \\
\text { Capital" }\end{array}$ & $\begin{array}{c}\text { Total } \\
\text { amount } € \\
500 \text { million }\end{array}$ & $\begin{array}{l}\text { Financing and } \\
\text { refinancing costs for } \\
\text { the purchase of electric } \\
\text { locomotives and } \\
\text { electric trains for } \\
\text { passenger } \\
\text { transportation }\end{array}$ & $\begin{array}{l}\text { Rating Agency } \\
\text { "Expert RA", } \\
\text { International } \\
\text { Capital Markets } \\
\text { Association } \\
\text { (ICMA) }\end{array}$ \\
\hline Bank Center-invest & $\begin{array}{l}\text { Moscow Exchange, } \\
\text { November 15, } 2019\end{array}$ & $\begin{array}{l}\text { The total } \\
\text { amount is } \\
250 \text { million } \\
\text { rubles. }\end{array}$ & $\begin{array}{l}\text { Financing and } \\
\text { refinancing loans for } \\
\text { the implementation of } \\
\text { energy efficiency } \\
\text { projects, the } \\
\text { development of } \\
\text { renewable energy } \\
\text { sources and } \\
\text { environmentally } \\
\text { friendly transport }\end{array}$ & $\begin{array}{l}\text { The issue is } \\
\text { included in the } \\
\text { Environmental } \\
\text { Finance Bond } \\
\text { Database, the } \\
\text { ICMA Green } \\
\text { database, the } \\
\text { Social and } \\
\text { Sustainability } \\
\text { bonds database, } \\
\text { and the Climate } \\
\text { Bonds Initiative } \\
\text { green bond } \\
\text { database. }\end{array}$ \\
\hline $\begin{array}{c}\text { Company } \\
\text { "Commercial real } \\
\text { estate FPK" Garant- } \\
\text { Invest " }\end{array}$ & $\begin{array}{l}\text { Moscow Exchange, } \\
\text { November 17, 2019, } \\
\text { placement organizers } \\
\text { - Global Markets, } \\
\text { Gazprombank, } \\
\text { Univer Capital, IC } \\
\text { Freedom Finance }\end{array}$ & $\begin{array}{l}\text { The total } \\
\text { amount is } \\
500 \text { million } \\
\text { rubles. }\end{array}$ & $\begin{array}{l}\text { The funds are directed } \\
\text { to finance the } \\
\text { modernization of } \\
\text { commercial real estate, } \\
\text { which provides for the } \\
\text { introduction of energy- } \\
\text { efficient and resource- } \\
\text { saving technologies } \\
\text { (green technologies) } \\
\text { under the investment } \\
\text { "PE Program" }\end{array}$ & $\begin{array}{l}\text { Conclusion of } \\
\text { "Expert RA" LLC } \\
\text { on the compliance } \\
\text { of the planned } \\
\text { bond issue with } \\
\text { the principles of } \\
\text { ICMA green } \\
\text { bonds }\end{array}$ \\
\hline LLC "SFO Rusol 1" & $\begin{array}{l}\text { Moscow Exchange, } \\
17 \text { February } 2020, \\
\text { Placement organizer } \\
\text { - Sovcombank }\end{array}$ & $\begin{array}{l}\text { The total } \\
\text { volume of } \\
\text { the three } \\
\text { issues is } 5.7 \\
\text { billion } \\
\text { rubles }\end{array}$ & $\begin{array}{l}\text { The funds are directed } \\
\text { to refinance bank loans } \\
\text { issued for construction } \\
\text { in the solar energy } \\
\text { sector }\end{array}$ & $\begin{array}{l}\text { Rating Agency } \\
\text { "Expert RA", } \\
\text { International } \\
\text { Capital Markets } \\
\text { Association } \\
\text { (ICMA) } \\
\end{array}$ \\
\hline $\begin{array}{l}\text { JSC "Russian } \\
\text { Railways" }\end{array}$ & $\begin{array}{l}\text { Moscow Exchange, } \\
\text { September 30, 2020, } \\
\text { Placement organizer } \\
\text { - PJSC VTB Capital, } \\
\text { Rosselkhozbank, } \\
\text { Sberbank KIB, } \\
\text { Sovcombank }\end{array}$ & $\begin{array}{l}\text { The total } \\
\text { amount is } \\
100 \text { billion } \\
\text { rubles. }\end{array}$ & $\begin{array}{l}\text { Funds are used to } \\
\text { finance green projects } \\
\text { of Russian Railways }\end{array}$ & $\begin{array}{l}\text { Rating Agency } \\
\text { "Expert RA", } \\
\text { International } \\
\text { Capital Markets } \\
\text { Association } \\
\text { (ICMA) }\end{array}$ \\
\hline
\end{tabular}

Source: (Compiled by the authors) 


\section{Results}

Under the influence of global trends, in August 2019, the Sustainable Development Sector, the first full-fledged platform for supporting environmental projects on the Russian financial market, was launched on the Moscow Exchange. As of November 1, 2020, five issuers in Russia have placed seven green bond issues for a total of 7.55 billion rubles. and $€ 500$ million. [4]

The analysis made it possible to conclude that despite the downturn in the Russian economy due to the coronavirus pandemic, over ten months of 2020 the volume of green bond placements has grown significantly. The following factors had a positive impact on this: the soft monetary policy of most of the world's regulators in response to the COVID-19 pandemic, the gradual decrease in the rate of the Central Bank of Russia to a record $4.25 \%$, which was a good incentive for refinancing loans and lengthening borrowing periods. Investors, in turn, showed increased interest in green bonds. An example of this can be Russian Railways, which placed in September 2020 the largest issue of green bonds in the amount of 100 billion. At the same time, the initial volume of the bonded loan was only 20 billion. Russian Railways confirmed that it is using the Environmental Strategy for the period up to 2020 and the outlook until 2030, providing for a reduction in the negative impact on the environment. In addition, the Company intends to implement a number of green projects. [5]

Such projects of the Company include projects of environmentally friendly transport (purchase of electric locomotives and electric trains for passenger transportation), construction of new, as well as reconstruction of existing railway lines, which will help reduce environmental impact, electrification of track sections to reduce greenhouse gas emissions, construction of treatment facilities for reducing emissions of pollutants.

\section{Discussion}

Based on the results of the study, we can conclude that the implementation of the UN goals in terms of combating climate change, industrialization, innovation and infrastructure, affordable and clean energy, clean water and sanitation, is carried out to a greater extent due to financial resources attracted from the placement of "green" bonds both in Russia and abroad. A large role in attracting such resources is assigned to banks and other financial institutions that act as intermediaries in the organization and implementation of the procedure for issuing "green" bondsThe main principle of which is that the funds received as a result of their emission are spent on the implementation of projects in the field of ecology and social sphere, which will undoubtedly lead to an improvement in the ecological situation in the world and the creation of more favorable conditions for the life of people.

Due to the fact that the procedures for issuing and verifying bonds as "green" are governed by the norms of international, regional and local legislation, there are significant contradictions in the indicated levels of regulatory and legislative acts that were not touched upon by this study, but are debatable and relevant today. In addition, the relevance of further research on the chosen topic is due to the dynamic growth of the eco - financial segment in the world, the current capacity of which is currently estimated at $\$ 800$ billion. Note that in 2012 the total volume of placement of green bonds on a global scale was only $\$ 2.6$ billion.

\section{Conclusion}

The rules for the placement of green and social bonds are only being developed today, among them are the requirement to disclose public non-financial reporting, possible measures to 
subsidize the coupon rate, compensation for verification costs, and others.

When passing the verification procedure for green bonds and projects, experts first of all check compliance with the Green Bond Principles (GBP) of the International Capital Market Association (ICMA), Climate Bonds Standard (CBS) International non-profit organization Climate Bonds Initiative (CBI).

One of the obstacles to the development of a green bond market is the scarcity of green projects and green assets, so policy measures to increase investment in green assets and infrastructure in the real economy are critical. This is clearly illustrated by the example of the European Union, which intends to make Europe a region with zero emissions by 2050 . Unsurprisingly, $45.4 \%$ of all green bonds issued in 2019 were issued in euros, followed by the dollar with $25.7 \%$. At the same time, the demand for "green" securities is also growing: about $9 \%$ of all debt obligations issued in euros in 2019 were "green", against slightly more than $2 \%$ of all dollar bonds.

The relevance of the topic for further research is due to the dynamic growth of the eco financial segment in the world, the current capacity of which is currently estimated at $\$ 800$ billion. Note that in 2012 the total volume of placement of green bonds on a global scale was only $\$ 2.6$ billion.

\section{References}

1. INFRAGREEN publishes an updated register of green and social bonds of Russian issuers. (2020). Retrieved from https://www.infragreen.ru/news/infragreen-publikuetobnovlennyj-reestr-zelenyx-i-soczialnyx-obligaczij-rossijskix-emitentov.html

2. I Galaktionov, Green bonds. Investments in the environment (2020). Retrieved from https://www.bcs-express.ru/novosti-i-analitika/zelenye-obligatsii-investitsii-vekologiiu.

3. A. Kidryeva, Audit in Russia: condition and prospects of development (2019). Retrieved from https://www.elibrary.ru/item.asp?id=42561597

4. E. Diba, «Green» financing in Russia: goals and contradictions of the modern market (2020). Retrieved from https://www.trends.rbc.ru/trends/green/5e9f373a9a79479d481053d2/

5. Y. Katasonova, Expert RA expressed an independent opinion on the compliance of Russian Railways' perpetual bonds with the principles of green bonds (2020). Retrieved from https://raexpert.ru/releases/2020/sep18b/ 